$$
\begin{aligned}
& \text { UCRL-CR--108120 } \\
& \text { DE92 } 003966
\end{aligned}
$$$$
\text { DEC } 1 \text { 2 } 1991
$$

\title{
Enhancing Sample Preparation Capabilities for Accelerator Mass Spectrometry Radiocarbon and Radiocalcium Studies
}

R. E. Taylor

University of California, Riverside

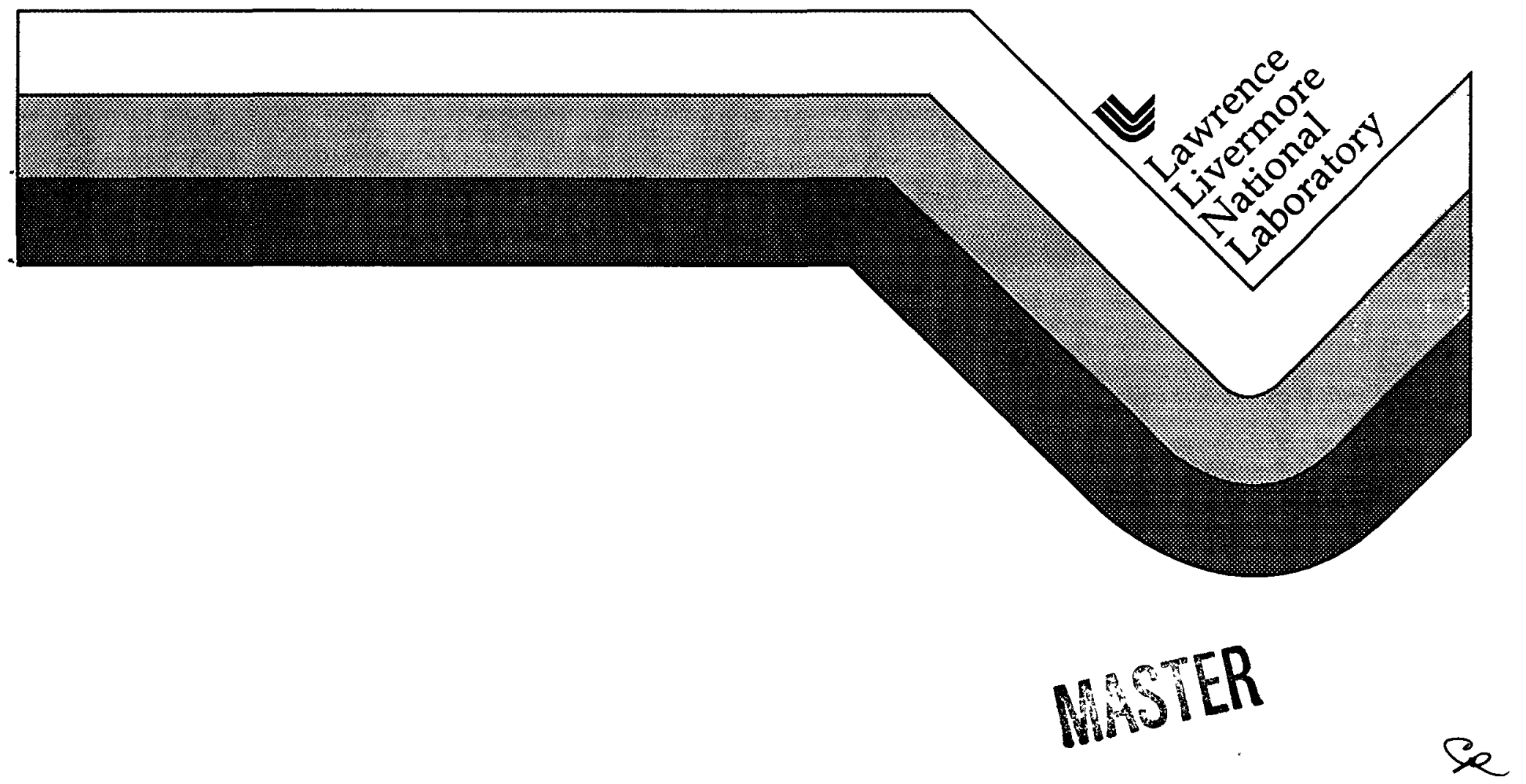




\section{DISCLAIMER}

This report was prepared as an account of work sponsored by an agency of the United States Government. Neither the United States Government nor any agency Thereof, nor any of their employees, makes any warranty, express or implied, or assumes any legal liability or responsibility for the accuracy, completeness, or usefulness of any information, apparatus, product, or process disclosed, or represents that its use would not infringe privately owned rights. Reference herein to any specific commercial product, process, or service by trade name, trademark, manufacturer, or otherwise does not necessarily constitute or imply its endorsement, recommendation, or favoring by the United States Government or any agency thereof. The views and opinions of authors expressed herein do not necessarily state or reflect those of the United States Government or any agency thereof. 


\section{DISCLAIMER}

Portions of this document may be illegible in electronic image products. Images are produced from the best available original document. 


\section{PROJECT REPORT}

Title of Project: Enhancing Sample Preparation Capabilities for Accelerator Mass Spectrometry Radiocarbon $\left({ }^{14} \mathrm{C}\right)$ and Radiocalcium $\left({ }^{41} \mathrm{Ca}\right)$ Studies: Continuing Research.

Principal Investigator: R. E. Taylor, Radiocarbon Laboratory, Department of Anthropology, Institute of Geophysics and Planetary Physics, University of California, Riverside 92521.

Associate Investigator: Peter J. Slota, Jr., Staff Research Associate, Radiocarbon Laboratory, University of California, Riverside 92521.

With support provided by the LLNL Accelerator Mass Spectrometry Laboratory, the UCR Radiocarbon Laboratory continued its studies involving sample pretreatment and target preparation for both AMS radiocarbon $\left({ }^{14} \mathrm{C}\right)$ and radiocalcium $\left({ }^{4} \mathrm{l}_{\mathrm{Ca}}\right)$ involving applications to archaeologically-and paleoanthropologically-related samples.

With regard to AMS ${ }^{14} \mathrm{C}$-related studies, we have extended the development of a series of procedures which have, as their initial goal, the capability to combust several hundred microgram amounts of a chemically-pretreated organic sample and convert the resultant $\mathrm{CO}_{2}$ to graphitic carbon which will consistently yield relatively high ${ }^{13} \mathrm{C}^{-}$ion currents and blanks which will yield, on a consistent basis, ${ }^{14} \mathrm{C}$ count rates at or below 0.208 modern, giving an 2 sigma age limit of $>50,000$ yr BP.

With LLNL support, we have constructed and are operating two additional vacuum lines. We have continued the work reported in slota and Taylor ${ }^{1}$ and Slota et al. ${ }^{2}$ which developed a graphite preparation method which eliminated the use of hydrogen. The method involves the reduction of $\mathrm{CO}_{2}$ to $\mathrm{CO}$ over $\mathrm{Zn}$

1. Slota, P. J. Jr. and R. E. Taylor, 1986 , AMS ${ }^{14} \mathrm{C}$ analysis of samples from archaeological contexts: Pretreatment and target preparation, in University of California AMS Conference Proceedings, Livermore: Institute of Geophysics and Planetary Physics.

2. Slota, P. J., Jr., A. J. T. Jull, T. W. Linck, and L. J. Toolin, 1987, Preparation of Small Samples for ${ }^{14} \mathrm{C}$ Accelerator Targets by Catalytic Reduction of CO, Radiocarbon 29:303-306. 
Project Report: Radiocarbon Laboratory, UC Riverside Page 3

reduce the possibility that bomb ${ }^{41_{C a}}$ would be introduced during sample preparation. We initiated our studies by examining procedures outlined by Sharma and Middleton ${ }^{3}$ which involved first the preparation of CaO followed by the a two-step reduction process which produces $\mathrm{Ca}$ metal and then, in the presence of $\mathrm{H}_{2}, \mathrm{CaH}^{2}$. In the original study, the chemical procedures involved in the preparation of $\mathrm{CaO}$ from bone was about $70 \%$ efficient. We undertook studies to attempt to increase extraction efficiency to at least 908. Experiments were conducted to simplify the procedures used to produce calcium metal from $\mathrm{CaO}_{2}$ but initial results were not encouraging due to inconsistent deposition of calcium metal in part due to difficulties with the RF induction heater employed. The need to reposition the apparatus from one laboratory to another interrupted these experiments. We intend to repeat them after acquisition of another RF induction heater.

Publications Which Include Data from LLNL AMS Laboratory

\section{Published}

Ajie, H. O., I. R. Kaplan, P. J. Slota, Jr., and R. E. Taylor 1990 AMS radiocarbon dating of bone osteocalcin. Nuclear Instruments and Methods in Physics Research B52:433-437.

In Press

(with expected publication dates in parenthesis)

Taylor, R. E.

(1991) Frameworks for Dating the Late Pleistocene Peopling of the Americas. In The First Americans: Search and Research, $T$. Dillehay and D. Meltzer, Eds. Boston: CRC Press.

S. Brooks, R. H. Brooks, G. Kennedy, P. Ennis, L. A. Payen, and R. E. Taylor.

(1991) The Haverty Human Skeletons: Evaluation of Morphological and Geochronological Characteristics. Journal of California and Great Basin Anthropology.

3Sharma, P. and R. Middleton, 1987, Sample preparation and production of negative ions of calcium hydride for ${ }^{41} \mathrm{Ca}$ AMS. Nuclear Instruments and Methods B29:63-66. 
Project Report: Radiocarbon Laboratory, UC Riverside

Page 4

Taylor, R. E.

(1992) Radiocarbon Dating by Accelerator Mass Spectrometry: An Archaeological Perspective. In Scientific Methods in Dating and Applications. Dordrecht (Netherlands): Kluwer Academic Publishers.

Taylor, R. E.

(1992) Radiocarbon dating of bone: To Collagen and Beyond. In R. E. Taylor, R. Kra, and A. Long, Eds., Four Decades of Radiocarbon Studies: An Interdisciplinary Perspective. New York: SpringerVerlag.

Taylor, R. E.

(1992) Radiocarbon Dating of Bone Using Accelerator Mass Spectrometry: Current Discussions and Future Directions. In Proceedings of the World Conference on the Peopling of the Americas, University of Maine, Orono.

Taylor, R. E., L. A. Payen, P. J. Slota, Jr.

(1992) The Age of the Calaveras Skull: Dating the "Piltdown Man" of the New World. American Antiquity.

\section{Submitted}

Ajie, H. O., I. R. Kaplan, P. V. Hauschka, D. Kirner, P. J. Slota, Jr., and R. E. Taylor

Radiocarbon dating of bone osteocalcin: Isolating and characterizing a non-collagen protein. Radiocarbon.

\section{In Preparation}

H. A. Simmons, L. A. Payen, P. J. Slota, Jr. and R. E. Taylor Pre-16th century European Materials at Drake's Bay, Oregon: A Possible Landing of Sir Francis Drake? Historical Archaeology

Papers Presented at Conferences Which Include Data from LINL AMS Laboratory

"AMS Radiocarbon Dating of Bone Samples" Conference on Problems of Dating of Pleistocene Contexts, University of Kansas, Lawrence, Kansas, March 27-28, 1990.

"Radiocarbon dating of bone of low and trace organic content: AMS ${ }^{14} \mathrm{C}$ analysis of osteocalcin" (with $\mathrm{H}$. O. Ajie, I. R. Kaplan, and P. J. Slota, Jr.) Fifth International Conference on Accelerator Mass Spectrometry, Paris, France, April 23-27, 1990.

"Radiocarbon Dating of Bone: Beyond Collagen" Conference on Four Decades of Radiocarbon Research: An Interdisciplinary Perspective. UC Lake Arrowhead Conference Center, Lake Arrowhead, California. June $4-8,1990$. 
Project Report: Radiocarbon Laboratory, UC Riverside Page 5

"Radiocarbon Dating of Bone Osteocalcin: Refinements in Procedures for Isolating a Pure Form of a Non-Collagen Protein." 14th

International Radiocarbon Conference, Tucson, Arizona, May 20-24, 1991 